\title{
Lead Activates Protein Kinase C in Immature Rat Brain Microvessels
}

\author{
JASNa MARKOVAC AND GARY W. GoldSTEIN \\ Departments of Pediatrics and Neurology. University of Michigan Medical School, Ann Arbor, Michigan 48109-0570
}

Received October 15, 1987; accepted June 12.1988

\begin{abstract}
Lead Activates Protein Kinase $\mathrm{C}$ in Immature Rat Brain Microvessels. MARKOVAC, J., AND GoldSTEIN, G. W. (1988). Toxicol. Appl. Pharmacol. 96, 14-23. We investigated the effects of inorganic lead upon calcium-, phospholipid-dependent protein kinase (protein kinase C) in brain microvessels isolated from 6-day-old rat pups. We found that (a) in broken cell preparations, lead at micromolar concentrations activates this enzyme to an extent equivalent to that of micromolar calcium $(10.3 \pm 1.3$ and $9.2 \pm 1.6 \mathrm{pmol} / \mathrm{mg} / \mathrm{min}$. respectively) and (b) preincubation of intact microvessels with lead results in a translocation of protein kinase $\mathrm{C}$ from the soluble to the particulate fraction. The cytosolic kinase activity stimulated by lead has the same requirements for diacylglycerol and phospholipid as the calcium-stimulated enzyme, suggesting that lead activates the kinase by mimicking calcium. The hypothesis that lead affects protein kinase $\mathrm{C}$ activity through a mechanism similar to that of calcium is supported by the similar time courses of substrate phosphorylation and dephosphorylation mediated by lead and calcium. When intact microvessels are preincubated with micromolar concentrations of lead. the translocation of protein kinase $C$ occurs in a dose- and time-dependent manner. The relocalization is virtually complete at $0.1 \mu \mathrm{M}$ lead and by $30 \mathrm{~min}$ of exposure. We propose that the sensitivity of protein kinase $\mathrm{C}$ to lead, described here in immature brain microvessels, makes this regulatory enzyme a potential mediator of lead toxicity. 1988 Academic Press, Inc.
\end{abstract}

Lead is a toxic metal, widely distributed in the environment, that remains a significant health hazard, particularly to children (Committee on Environmental Hazards and Committee on Accident and Poison Prevention, 1987). The biochemical mechanisms mediating this toxicity are unclear, but in several biologic systems. lead alters calcium-mediated cellular processes (Pounds, 1984; Simons, 1986) and may mimic calcium in binding to regulatory proteins (Habermann and Richardt, 1986). Capillaries in the brain are a major target tissue for the toxic action of lead (Press, 1985). Pathologic studies in children poisoned with lead and in several animal models of lead toxicity reveal a breakdown in the normally tight blood-brain barrier (Goldstein, 1984; Clasen et al., 1974). The formation of the blood-brain barrier is the result of the special structure of brain microvessels (Reese and Karnovsky, 1967) made up of endothelial cells lacking fenestrae and transcellular channels. The cells are joined together by continuous complex tight junctions which limit transcapillary movement of proteins, organic molecules, and ions (Bradbury, 1985; Betz, 1986). In vivo studies demonstrate that lead accumulates in brain microvessels (Toews et al.. 1978; Thomas et al., 1973) and markedly increases their permeability, especially in immature animals (Pentschew and Garro, 1966; Goldstein et al., 1974; Roy et al., 1974). We used microvessels isolated from immature rat brain to study the cellular mechanisms involved in this toxic reaction.

Brain microvessels are most vulnerable to lead early in development when they are proliferating (Press, 1977). The toxic injury results in loss of specific differentiated functions and a breakdown of the blood-brain barrier. In several other tissues, lead is known 
to alter the metabolism of calcium (Pounds, 1984: Simons, 1986) and we believe that calcium-mediated events are likely cellular targets for the changes in brain capillary permeability induced by lead.

Protein kinase C, a calcium-, phospholipid-dependent enzyme closely associated with signal transduction, phosphorylates critical regulatory proteins and thus modulates cellular proliferation and differentiation (for review, see Nishizuka, 1986a). The enzyme is activated by diacylglycerol, a second messenger transiently produced by receptor-mediated hydrolysis of inositol phospholipids (Sano et al., 1983). An additional second messenger, inositol trisphosphate, also resulting from this hydrolysis, ultimately affects the intracellular mobilization of calcium (Berridge and Irvine, 1984). We chose to investigate the effect of lead on protein kinase $C$ because it is regulated by calcium (Takai et al., 1979) and plays a pivotal role in the control of cellular growth and differentiation. We examined this effect both in broken cell preparations and in intact microvessels isolated from immature rat brain. Here we present evidence that micromolar concentrations of lead (a) stimulate diacylglycerol-activated, phospholipid-dependent protein kinase in cytoslic extracts of rat brain microvessels to an extent equivalent to that of micromolar calcium and (b) cause the translocation of this enzyme from the cytosol into the membranc, in intact microvascular cells, in a doseand time-dependent manner.

\section{METHODS}

Materials. Six day-old Sprague-Dawley rat pups were obtained from Harlan (Haslett, MI). $\gamma-\left[{ }^{32}\right.$ P]ATP $(4000$ $\mathrm{Ci} / \mathrm{mmol}$ ) was purchased from ICN Biomedicals, Inc. (Irvine, CA). 1,2-Diolein was obtained from P-L Biochemicals (Milwaukee, WI). Type III-S histone, phosphatidyl-L-serine, ATP, and all other reagents were obtained from Sigma (St. Louis, MO). Phosphocellulose paper (P81) was obtained from Whatman (Hillsboro, OR).

Isolation of rat brain microvessels. Microvessels were isolated from cortical hemispheres of 6-day-old Sprague Dawley rat pups by modification of a technique previously described (Betz and Goldstein. 1981). The ani- mals were killed by decapitation and the brains rapidly removed and placed in ice-cold Medium 199 buffered with $20 \mathrm{mM} N$-2-hydroxyethylpiperazine- $N$-2-ethanesulfonic acid (Hepes), pH 7.4 (buffer A). The brainstem, cerebellum, and meninges were discarded and the cortical shells, free of choroid plexus and ependyma, were minced in above buffer. Following homogenization (20 strokes. $390 \mathrm{rpm})$ in a Teflon/glass homogenizer $(0.25$ $\mathrm{mm}$ clearance), a $10 \%$ suspension $(\mathrm{w} / \mathrm{v})$ was centrifuged at $1000 \mathrm{~g}$ for $10 \mathrm{~min}$. To remove myelin and cellular debris, the pellet was suspended to $16 \%(\mathrm{w} / \mathrm{v})$ in buffer $\mathrm{A}$ containing $15 \%$ dextran and centrifuged at $4000 \mathrm{~g}$ for 10 min. The resulting pellet, consisting of free nuclei and capillary segments, was resuspended in buffer $\mathrm{A}$ and gently suctioned through a $118-\mu \mathrm{m}$ nylon mesh. To isolate the capillaries from nuclear debris, the suspension was subsequently passed over a $1.2 \times 1.5-\mathrm{cm}$ column of $0.25-\mathrm{mm}$ glass beads supported on a $53-\mu \mathrm{m}$ nylon mesh and washed extensively with the buffer. The capillary segments, retained on the column, were recovered by gentle agitation of the glass beads in same buffer, decanted, and collected by centrifugation at $500 \mathrm{~g}$ for $5 \mathrm{~min}$. The quality of each preparation was judged morphologically under phase microscopy (Fig. 1).

Incubation of microvessels. For preincubation with lead, the microvessels, prepared as described above, were divided into the desired number of aliquots, centrifuged at $500 \mathrm{~g}$ for $5 \mathrm{~min}$, and resuspended in buffer A containing specified concentrations of lead acetate ( $\mathrm{PbOAc}$ ). The capillary suspensions were incubated at $37^{\circ} \mathrm{C}$ for $45 \mathrm{~min}$, unless otherwise noted. The suspensions were then pelleted by centrifugation at $500 \mathrm{~g}$ for $5 \mathrm{~min}$ and prepared for protein kinase $C$ assay as described below.

Extract preparation. To prepare a cytosolic extract for the assay of protein kinase activity, isolated microvessels were washed twice with ice-cold calcium-free phosphatebuffered saline. pH 7.4, sonicated for $15 \mathrm{sec}$ in buffer containing $20 \mathrm{~mm}$ Hepes, $\mathrm{pH}$ 7.5, $2 \mathrm{~mm}$ ethylenediaminetetraacetic acid (EDTA), $2 \mathrm{~mm}$ ethyleneglycol-bis-( $\beta$-aminoethyl ether) $N, N, N^{\prime}, N^{n}$-tetraacetic acid (EGTA), $0.25 \mathrm{M}$ sucrose, and $10 \mathrm{mM} \beta$-mercaptoethanol (buffer $B$ ). and then centrifuged for $1 \mathrm{hr}$ at $40,000 \mathrm{~g}$. The resulting supernatant fraction was used for all subsequent experiments except where otherwise noted. When appropriate, the pellets from the $40,000 \mathrm{~g}$ centrifugation were solubilized in $0.03 \%$ Triton X-100 (in buffer B) and assayed for protein kinase $\mathrm{C}$ activity in the presence of $10 \mu \mathrm{M} \mathrm{CaCl}_{2}$, as described below.

Assay for protein kinase $C$. Protein kinase activity was assayed by a modification of the procedure described by Takai et al. (1979), measuring the incorporation of radiolabel from $\left[{ }^{32} \mathrm{P}\right] \mathrm{ATP}$ into endogenous cytosolic protein and exogenous lysine-rich histones. In a total volume of $250 \mu \mathrm{l}$, the standard reaction mixture contained $20 \mathrm{mM}$ Tris- $\mathrm{HCl}(\mathrm{pH} 7.4), 5 \mathrm{mM} \mathrm{MgCl}_{2}, 5 \mu \mathrm{g}$ phosphatidylserine, $5 \mu \mathrm{g} \mathrm{1,2-diolein} \mathrm{(or} \mathrm{equivalent} \mathrm{volume} \mathrm{of} \mathrm{ddH}_{2} \mathrm{O}$ ), $20 \mu \mathrm{g}$ lysine-rich histones, $0.2 \mathrm{nmol}$ ATP, $\left.2 \mu \mathrm{Ci} \mathrm{[}{ }^{32} \mathrm{P}\right] \mathrm{ATP}$ $\left(4000 \mathrm{Ci} / \mathrm{mmol}\right.$ ), and $10 \mu \mathrm{M} \mathrm{CaCl}_{2}$ or $10 \mu \mathrm{M} \mathrm{PbOAc}$ (un- 


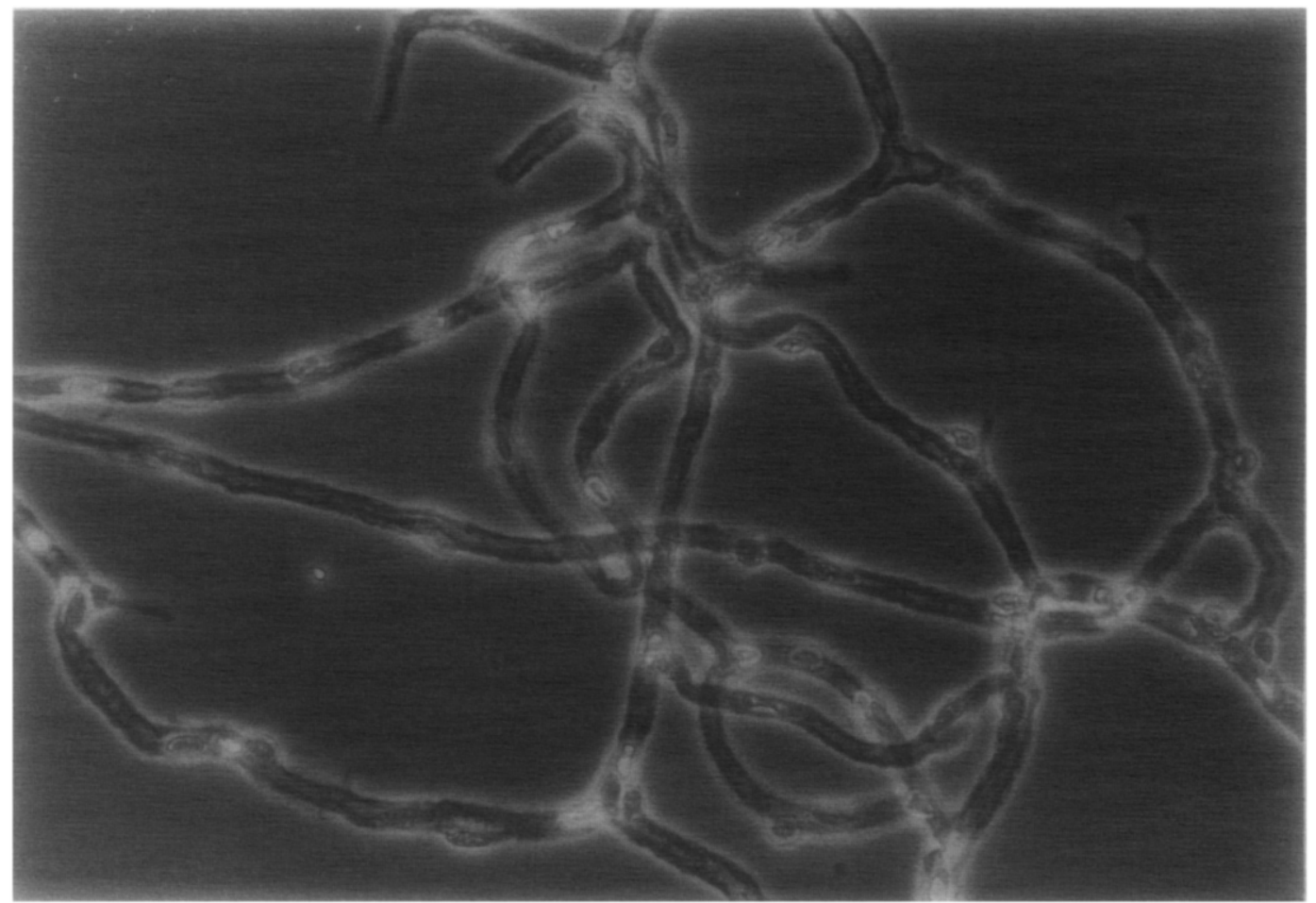

FIG. 1. Isolated immature microvessels. Microvessels were isolated from 6-day-old rats as described under Methods. Light phase contrast micrograph indicates segments of microvessels essentially free of debris $(\times 380)$.

less otherwise noted). The reaction was initiated by addition of $100 \mu \mathrm{l}$ extract containing $5-15 \mu \mathrm{g}$ cytosolic or membranous protein, incubated for $5 \mathrm{~min}$ at $30^{\circ} \mathrm{C}$, and terminated by addition of $75 \mu \mathrm{l}$ of $12 \mathrm{~N}$ glacial acetic acid. Phosphorylated proteins were collected by adsorption on P81 phosphocellulose papers. The filters were washed once in $30 \%$ acetic acid, twice in $15 \%$ acetic acid, and finally in acetone. The radioactivity was quantitated by Cerenkov counting and protein content determined by the method of Bradford (1976). Protein kinase activity was calculated as the difference in the activity in the presence and absence of 1,2-diolein.

\section{RESULTS}

The toxic effects of lead are thought, at least in part, to be due to its interference in calcium-mediated cellular function. Because brain capillaries are particularly vulnerable, purified microvessels provide a model system for the study of these effects. We investigated the ability of lead to affect protein kinase $C$ in (a) broken cell preparations of microvessels isolated from immature rat brain and (b) intact capillary segments.

Protein kinase $\mathrm{C}$, in most tissues other than brain, is found in the cytosolic fraction (Kikkawa et al., 1982; Girard et al., 1986). We determined that in immature brain microvessels, this enzyme is recovered mainly from the soluble fraction in contrast with that from 6-day-old whole brain where it is almost completely particulate (data not shown). Thus, all subsequent results using broken cell preparations were obtained with cytosolic fractions. Soluble protein kinase activity in disrupted cellular extracts was measured as diacylglycerol-specific incorporation of radiolabel from $\left[{ }^{32}\right.$ P]ATP into exogenous lysine-rich histones and endogenous cytosolic proteins in the presence of lead or calcium.

Figure 2 illustrates the stimulation of soluble protein kinase as a function of the concen- 


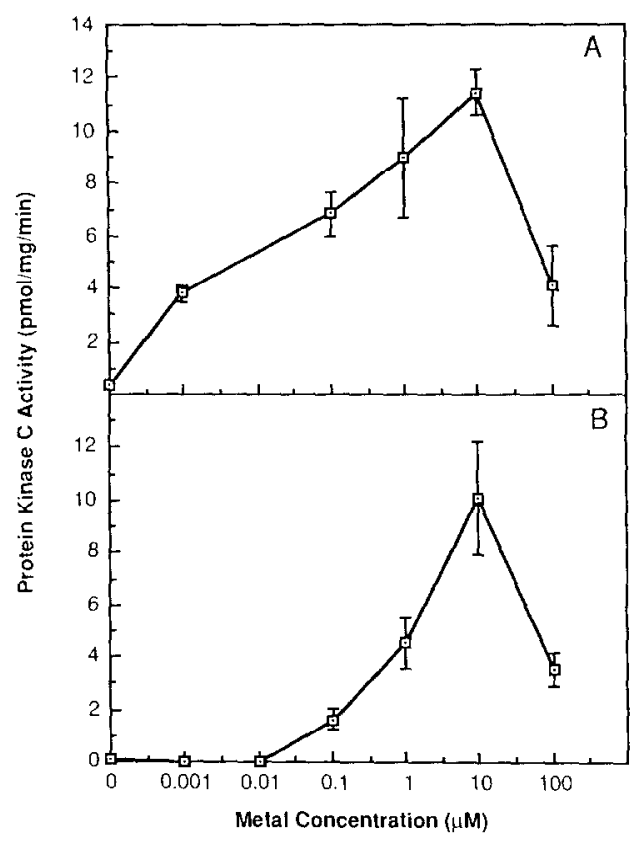

FIG. 2. Dose-dependent stimulation of protein kinase activity by calcium and lead. Cytosolic diacylglycerol-activated. phospholipid-dependent protein kinase was measured in the presence of varying concentrations $(0-$ $100 \mu \mathrm{M}$ ) of calcium (A) or lead (B). Values plotted are the means of three replicates $\pm S E$. Data points without error bars represent $\mathrm{SE}<5 \%$. Equivalent results were obtained in three separate experiments.

tration of calcium (Fig. 2A) and lead (Fig. 2B). There was no detectible diacylglycerol-, phospholipid-dependent protein kinase activity in the absence of either cation. At concentrations of less than $1 \mu \mathrm{M}$, calcium appears to be more potent in the stimulation of protein kinase activity than lead. However, with increasing concentrations of both calcium and lead, kinase activity increased, peaked at $10 \mu \mathrm{M}$, and then declined. The decrease in activity observed in the calcium dose-response curves is thought to reflect a reduced affinity of protein kinase $\mathrm{C}$ for diacylglycerol at higher concentrations of calcium (for review, see Nishizuka, 1986a). The similar decline at higher concentrations of lead suggests an analogous mechanism for protein kinase activation.

Because of the apparent difference between calcium and lead in their ability to stimulate protein kinase activity at lower concentrations (Fig. 2), we investigated the combined effects of these two cations upon protein kinase C. Figure 3 illustrates the effects of 0.1 $\mu \mathrm{M}$ calcium, of $0.1 \mu \mathrm{M}$ lead, and of lead and calcium together in the stimulation of protein kinase activity. In this experiment, lead and calcium were equally potent in the activation of the enzyme. When lead and calcium were tested together, protein kinase $\mathrm{C}$ activity was somewhat greater than in the presence of either cation alone.

We then established that the kinase activity stimulated by $10 \mu \mathrm{M}$ lead has the same requirements for diacylglycerol as the calciumstimulated enzyme. With varying amounts of 1,2-diolein $(0-30 \mu \mathrm{g} / \mathrm{ml})$, we found no apparent difference in diacylglycerol-dependent activation of protein kinase between $10 \mu \mathrm{M}$ calcium and $10 \mu \mathrm{M}$ lead (Fig. 4). Similar experiments were performed using varying concentrations of phospholipid (phosphatidylserine, 0-25 $\mu \mathrm{g} / \mathrm{ml}$ ). Again, stimulation with either calcium or lead resulted in no significant difference in the phospholipid dose-dependent activation of protein kinase (data not shown). These results suggest that the cytosolic extracts of protein kinase activity stimulated by micromolar concentrations of lead are similar to if not the same as calcium-, phospholipid-dependent protein kinase (protein kinase C). Thus, lead may be activating this enzyme by mimicking calcium.

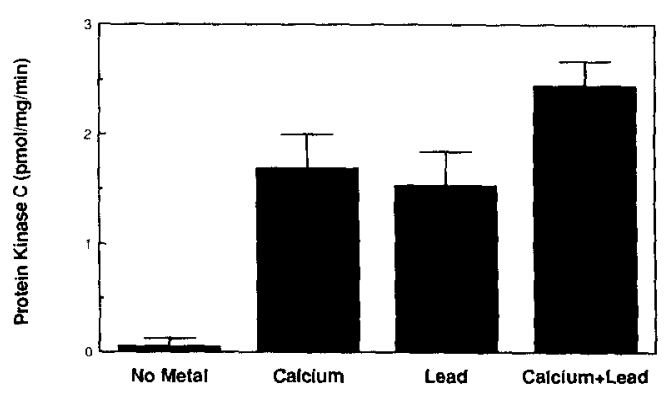

FIG. 3. Effects of $0.1 \mu \mathrm{M}$ calcium and lead upon protein kinase activity. Cytosolic diacylglycerol-activated, phospholipid-dependent protein kinase was measured in the presence of $0.1 \mu \mathrm{M}$ calcium, $0.1 \mu \mathrm{M}$ lead, or both calcium and lead. Values plotted are the means of three replicates $\pm \mathrm{SE}$. 


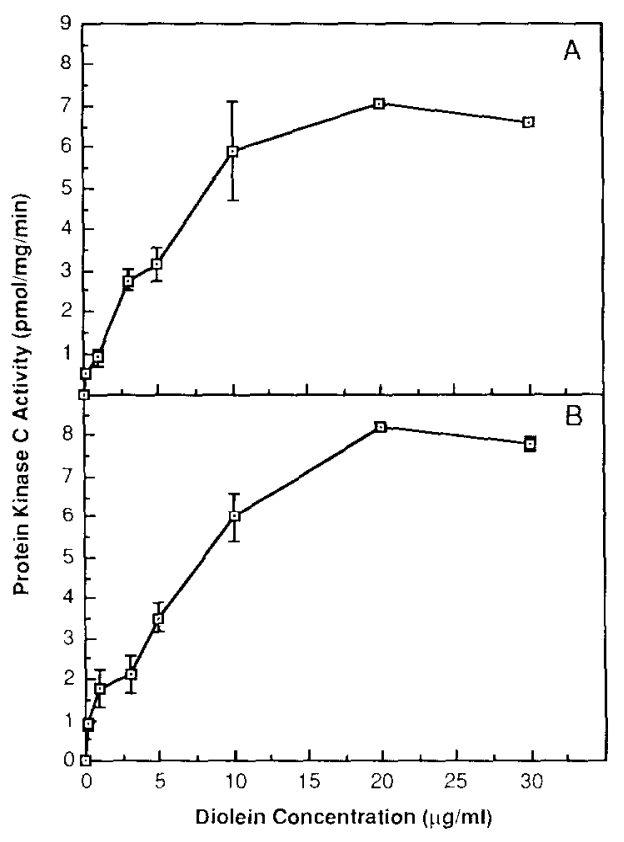

FIG. 4. Diacylglycerol-dependent activation of cytosolic protein kinase in the presence of calcium or lead. Diacylglycerol requirements of phospholipid-dependent protein kinase were tested in the presence of (A) $10 \mu \mathrm{M}$ calcium or (B) $10 \mu \mathrm{M}$ lead. $\mathrm{CaCl}_{2}$ or $\mathrm{PbOAc}$ was added to the standard reaction mixture and the kinase activity assayed in the presence of various amounts of 1.2-diolein $(0-30 \mu \mathrm{g} / \mathrm{ml})$. Values plotted are the means of three replicates $\pm \mathrm{SE}$. Data points without error bars represent $\mathrm{SE}$ $<5 \%$.

To further investigate this possibility, we determined the time dependence of substrate phosphorylation and dephosphorylation mediated by both calcium and lead. The time course of the reaction in the presence of 10 $\mu \mathrm{M}$ calcium or $10 \mu \mathrm{M}$ lead is illustrated in Fig. 5 . The data reflect quantities of phosphorylated protein resulting from the sum of phosphorylation and dephosphorylation reactions. We find that protein phosphorylation increased until $10 \mathrm{~min}$ of incubation time and then plateaued. After $30 \mathrm{~min}$, the amount of phosphorylated protein decreased, reaching essentially zero by $1 \mathrm{hr}$. As well as reflecting reduced substrate phosphorylation, this decline also reflects phosphatase activity. The general shapes of the curves resulting from incubation by both cations are very similar, suggesting a common mechanism of action for calcium and lead upon protein kinase $\mathrm{C}$ activity.

In order to demonstrate that the protein $\mathrm{ki}$ nase $C$ activation we observed is due to lead and not to the anionic component of lead acetate, we examined the effects of various lead salts for their ability to stimulate this enzyme. Lead acetate, citrate, and chloride all activate this enzyme at concentrations of $10 \mu \mathrm{M}$ compared with basal levels (no lead or calcium). Sodium acetate has no significant effect on protein kinase activity (Table 1) indicating that the stimulation of protein kinase $C$ is due to lead and not to an anionic interaction of acetate with the enzyme.

Having demonstrated that lead is able to stimulate soluble protein kinase $C$ activity in broken cell preparations of immature brain microvessels, we then investigated its effects

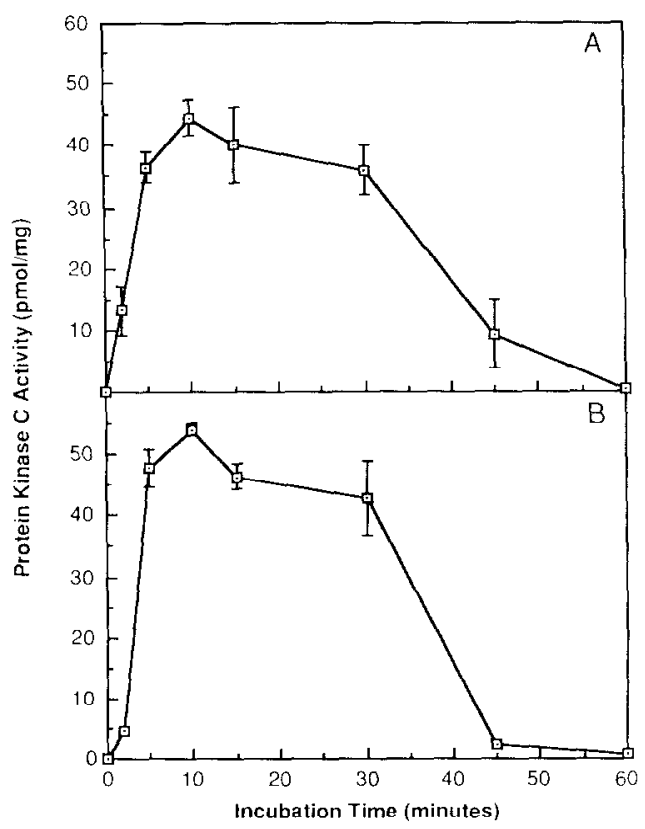

FIG. 5. Stimulation of cytosolic protein kinase activity by lead or calcium at variable incubation times. Diacylglycerol-stimulated, phospholipid-dependent protein kinase activity was assayed in the presence of (A) $10 \mu \mathrm{M}$ calcium and (B) $10 \mu \mathrm{M}$ lead at incubation times from 0 to $60 \mathrm{~min}$. Values plotted are the means of three replicates $\pm \mathrm{SE}$. Data points without error bars represent $\mathrm{SE}$ $<5 \%$. 


\section{TABLE I}

EfFect of LeAd Salts and Sodium Acetate on CYTOSOLIC PROTEIN KINASE ACTIVITY ${ }^{a}$

\begin{tabular}{lcc}
\hline \multicolumn{1}{c}{ Salt } & $N$ & $\begin{array}{r}\text { Protein kinase C } \\
(\mathrm{pmol} / \mathrm{mg} / \mathrm{min})\end{array}$ \\
\hline None & 3 & $0.16 \pm 0.16$ \\
$\left.\mathrm{Ph} \mathrm{C}_{2} \mathrm{H}_{3} \mathrm{O}_{2}\right)_{2}$ & 3 & $10.13 \pm 0.28$ \\
$\mathrm{PbCl}_{2}$ & 3 & $8.74 \pm 1.43$ \\
$\mathrm{~Pb}_{3}\left(\mathrm{C}_{6} \mathrm{H}_{5} \mathrm{O}_{7}\right)_{2} \cdot 3 \mathrm{H}_{2} \mathrm{O}$ & 3 & $7.42 \pm 0.67$ \\
$\mathrm{NaC}_{2} \mathrm{H}_{3} \mathrm{O}_{2}$ & 2 & $0.25 \pm 0.25$ \\
\hline
\end{tabular}

"Soluble protein kinase was activated by addition of 10 $\mu \mathrm{M}$ specified compound to standard reaction mixture, omitting calcium (see Methods). Values represent means \pm SE.

on the intact capillary. When isolated microvessels were preincubated with micromolar concentrations of lead acetate, protein $\mathrm{ki}$ nase $C$ activity becomes redistributed from the cytosolic to the particulate fraction. Protein kinase $\mathrm{C}$ activity in lead-treated microvessels, subsequently fractionated into soluble and particulate components, was assayed in the presence of $10 \mu \mathrm{M}$ calcium. We find no change in total protein kinase $\mathrm{C}$ activity in response to lead, suggesting that this toxin redistributes but does not further activate the enzyme. Figure 6 illustrates the dosedependent translocation of this enzyme in response to lead, with complete particulate recovery occurring between 0.01 and $0.1 \mu \mathrm{M}$. At $1 \mu \mathrm{M}$ lead, the movement of protein kinase $C$ from the cytosol into the membrane occurs in a time-dependent manner and is complete by $30 \mathrm{~min}$ (Fig. 7 ).

\section{DISCUSSION}

Protein kinase $C$ phosphorylates various critical cell membrane and transport proteins (Hunter et al., 1984; Witters et al., 1985; Albert et al., 1984) and thus represents a major site for regulation of cellular growth and differentiation (Nishizuka, 1984). Here, we present evidence that lead activates a brain microvessel protein kinase similar to protein

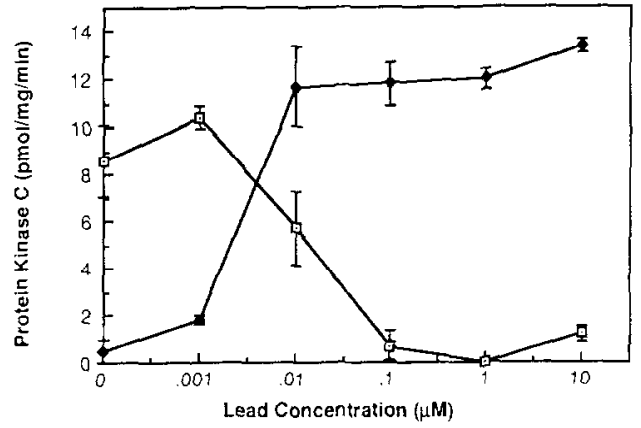

FIG. 6. Effect of varying concentrations of lead exposure on isolated microvascular protein kinase C. Microvessels were incubated with varying concentrations of lead $(0-10 \mu \mathrm{M})$ for $45 \mathrm{~min}$ at $37^{\circ} \mathrm{C}$ while under gentle agitation. Disrupted cell suspension was fractionated into soluble ( $\square$ ) and particulate $(\boldsymbol{\square})$ components and protein kinase $C$ activity assayed as described under Methods. Values plotted are the means of three replicates $\pm \mathrm{SE}$. Data points without error bars represent $\mathrm{SE}<5 \%$.

kinase $C$. The lead-induced activation occurs in a dose-dependent manner, peaking at 10 $\mu \mathrm{M}$, then declining, similar to that observed with calcium (Fig. 2). While the apparent $V_{\text {max }}$ of this kinase for both cations is similar, at concentrations of less than $1 \mu \mathrm{M}$, the affinity for calcium appears to be greater than that for lead. When cytosolic extracts were exposed to both $0.1 \mu \mathrm{M}$ calcium and $0.1 \mu \mathrm{M}$

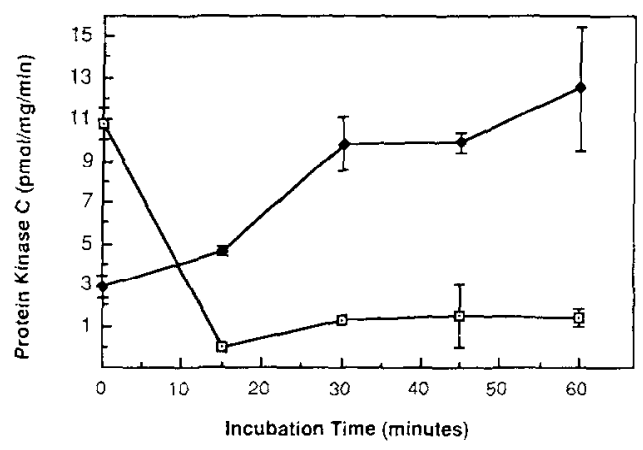

FIG. 7. Effect of lead exposure for varying intervals upon microvascular protein kinase $\mathrm{C}$. Microvessels were exposed to $1 \mu \mathrm{M}$ lead at $37^{\circ} \mathrm{C}$ for varying incubation periods ( 0 to $60 \mathrm{~min}$ ). Disrupted cell suspension was fractionated into soluble $(\square)$ and particulate ( $\square$ ) components and protein kinase $C$ activity assayed as described under Methods. Values plotted are the means of three replicates \pm SE. Data points without error bars represent $\mathrm{SE}<5 \%$. 
lead, the amount of protein phosphorylation increased compared to activation by each cation alone (Fig. 3). Thus, lead does not appear to antagonize the induction of this enzyme by calcium. Our observations are physiologically relevant in that intracellular calcium concentrations are known to be in the range of $0.1 \mu \mathrm{M}$ (Pounds, 1984). To our knowledge, intracellular concentrations of lead have not been determined in exposed tissues. Further investigation of the kinetics of protein kinase $C$ in response to calcium and lead, particularly at low concentrations, will require purification of protein kinase C. At $10 \mu \mathrm{M}$ lead, the requirements of the protein kinase for diacylglycerol as well as for phospholipid were the same as those found at $10 \mu \mathrm{M}$ calcium (Fig. 4), the standard condition for assay of protein kinase $C$. This suggests that lead mimics calcium in the activation of this enzyme in vitro.

An alternate explanation for the increase in substrate phosphorylation produced hy lead is that instead of activating a kinase, lead inhibits a phosphatase responsible for phosphoprotein degradation. We believe that this explanation is unlikely in view of the similarity between the time courses of substrate phosphorylation and dephosphorylation produced by lead and calcium (Fig. 5). Furthermore, both cations have a nearly identical requirement for diacylglycerol and phospholipid in their stimulation of substrate phosphorylation. It should also be noted that the proteins targeted by protein kinase $C$ can remain phosphorylated for long periods of time because they are generally more resistant to phosphatase action than the substrates of other protein kinases (Kikkawa and Nishizuka, 1986). Since lead-induced increase in substrate phosphorylation occurs within minutes, it is likely that this change represents stimulation of protein kinase rather than inhibition of phosphatase activity.

Having demonstrated that lead is able to stimulate a soluble protein kinase in disrupted immature brain microvessels, we then investigated the effects of this heavy metal upon protein kinase $\mathrm{C}$ in intact microvessels.
Exposure of the microvessels to micromolar concentrations of lead resulted in the disappearance of protein kinase $C$ activity from the cytosol and its appearance in the membrane fraction. This apparent translocation was dose dependent and all the enzyme activity was recovered in the particulate fraction at $0.1 \mu \mathrm{M}$ lead (Fig. 6). This effect was also time dependent and complete by $30 \mathrm{~min}$ of exposure to lead (Fig. 7). The "normal" blood lead concentration is between 5 and $25 \mu \mathrm{g} / 100 \mathrm{cc}$ of whole blood or $10^{-6} \mathrm{M}$ (Mahaffey et al. 1982). Because $95-98 \%$ is bound to red blood cells, approximately $10^{-8} \mathrm{M}$ remains in the plasma (Clarkston and Kench, 1958). Thus, the concentration of lead which results in the apparent translocation of protein kinase $C$ from the cylosol into the membrane is consistent with toxic exposures. This important regulatory enzyme, then. represents a possible mediator of lead toxicity.

The interaction between lead and calcium has been investigated in various biologic systems (for review, Simons, 1986). Exposure to lead enhances calcium uptake in several tissues (Pounds, 1984). We believe that the apparent redistribution of protein kinase $C$ in response to lead exposure is a direct effect of the toxicant and not due to its influence upon calcium uptake because calcium alone does not translocate protein kinase $C$ in the $a b-$ sence of specific agonists. To prove this hypothesis, additional investigation of the effect of lcad upon phosphoinositol turnover and diacylglycerol formation is required.

Protein kinases, in response to specific stimuli, phosphorylate substrate proteins and thus alter the properties of those proteins to produce the physiological responses characteristic for the stimulating agent (Nessler and Greengard, 1984: Cohen, 1982). Protein phosphatases counter the actions of protein kinases by dephosphorylating their target proteins. The activation of protein kinases by hormones and polypeptide growth factors generally is thought to occur through receptor-mediated second messengers. When the appropriate agonist binds to a specific cell surface receptor, it can stimulate the metabo- 
lism of phosphatidylinositol lipids in the cell membrane. This is accomplished through the activation of a specific phosphodiesterase (phospholipase $C$ ) presumably via a guanine nucleotide-binding protein ( $G$ protein) and results in the generation of two second messengers, inositol trisphosphate and diacylglycerol. Inositol trisphosphate mediates the mobilization of intracellular calcium from the endoplasmic reticulum, increasing calcium concentrations within the cell. Diacylglycerol activates protein kinase $C$, a calciumdependent enzyme, by translocating it from the cytosol into the membrane. This redistribution can be accompanied by an increase in total activity (for review, see Kikkawa and Nishizuka, 1986). In isolated brain microvessels, as in several other tissues (Homma et al., 1986; Chida et al., 1986), further protein kinase $C$ activation does not accompany translocation. Once protein kinase $C$ becomes associated with the membrane, the enzyme phosphorylates critical regulatory proteins which may ultimately control growth and differentiation (Nishizuka, 1986b). Protein kinase $C$ can, for example, regulate transmembrane signaling by phosphorylating and thus down-regulating membrane receptors such as that for epidermal growth factor (Hunter et al., 1984).

We have shown that, in isolated immature brain microvessels, lead can substitute for calcium in the stimulation of soluble diacylglycerol-activated, phospholipid-dependent protein kinase in broken cell preparations. In addition, using intact microvascular cells, we found that exposure to lead produces a translocation of protein kinase $\mathrm{C}$ activity from the cytosol to the membrane. Lead is known to mimic calcium in various other biologic systems (Pounds et al., 1982; Pounds and Mittelstaedt, 1983; Goldstein and Ar, 1983). Several components of the phosphoinositide turnover system are calcium dependent (Majerus et al., 1985; Berridge and Irvine, 1984). These include the phosphodiesterases that convert inositol phospholipids to diacylglycerol and protein kinase $\mathrm{C}$ itself. By interacting with calcium in this second messenger pathway, lead may ultimately affect growth and differentiation. Lead also alters another second messenger, cyclic AMP, by altering postsynaptic catecholamine action (Taylor $e t$ al., 1978) and inhibiting adenylate cyclase (Nathanson and Bloom, 1975). 12-O-Tetradccanoyl phorbol-13-acetate (TPA), a phorbol ester tumor promoter that is a potent activator of protein kinase C (Niedel et al., 1983; Castagna et al., 1982; Kikkawa et al., 1983), can phosphorylate the catalytic unit of adenylate cyclase. Purified protein kinase $C$ is reported to phosphorylate this enzyme in vitro (Yoshimasa et al., 1987). Lead, by activating protein kinase $C$, could therefore interact with other second messenger systems.

Inorganic lead is a mitogen for several cell types. Exposure of rat kidney cells to lead results in increased proliferation (Choie and Richter, 1972). In mouse kidney cells, lead stimulates DNA, RNA, and protein synthesis (Choie and Richter, 1974a,b). Both parenchymal and nonparenchymal rat liver cells, following a single exposure to lead, show an increase in the number of mitotic cells, as well as in total DNA and protein content (Columbano et al., 1983). The mechanisms mediating the mitogenic effects of lead are unknown. Our results suggest that investigations of the activity and distribution of protein kinase $\mathrm{C}$ may be fruitful given the importance of protein kinase $C$ in the regulation of growth.

Immature proliferating microvessels in brain are the ones most vulnerable to injury by lead (Press, 1985). A separation of tight junctions which normally seal the endothelial cells together in brain microvessels is found in lead encephalopathy (Lampert et al., 1969). Support for a role of protein kinase C in this reaction is provided by the opening of tight junctions between kidney epithelial cells produced by the protein kinase $\mathrm{C}$ activator, TPA (Ojakian, 1981). Unregulated activation by lead of protein kinase $\mathrm{C}$ in immature microvessels could therefore produce separation of tight junctions and ultimately brain edema. 
We propose that the ability of lead to activate protein kinase $C$, described here in immature brain microvessels, makes this regulatory enzyme a potential mediator of lead toxicity upon the blood-brain barrier. Abnormal activation of microvascular protein kinase $C$ may also underlie lead toxicity in other tissues.

\section{ACKNOWLEDGMENT}

This work was supported by Grant ES02380 from the National Institutes of Health.

\section{REFERENCES}

Aibert. K. A.. Helmer-Matyifk. E. Nairn, A. C., Muller, T. H., Haycock, J. W., Greene. L. A., Goldstein, M., AND Greengard. P. (1984). Calcium/phospholipid-dependent protein kinase (protein kinase C) phosphorylates and activates tyrosine hydroxylase. Proc. Natl. Acad. Sci. USA 81, 7713-7717.

BERRIDGE, M. J., AND IR VINE, R. F. (1984). Inositol trisphosphate, a novel second messenger in signal transduction. Nature (London) 312, 315-321.

BETZ, A. L. (1986). Transport of ions across the bloodbrain barrier. FASEB 45, 2050-2054.

Betz, A. L., And Goldstein. G. W. (1981). Development changes in metabolism and transport properties of capillaries isolated from rat brain. J. Physiol (London) 312, 365-376.

BRADBURY, M. W. B. (1985). The blood-brain barrier: Transport across the cerebral endothelium. Circ. Res. 57. 213-222.

BRADFORD, M. M. (1976). Rapid and sensitive method for the quantitation of microgram quantities of protein utilizing the principle of protein-dye binding. Anal. Biochem. 72, 248-254.

Castagna, M.. Takal, Y., Kaibuchi, K., Sano, K., KiKkaWA, U., AND NishizUKa, Y. (1982). Direct activation of calcium-activated, phospholipid-dependent protein kinase by tumor-promoting phorbol esters. J. Biol Chem. 257, 7847-7851

Chida, K., Hashiba, H., Sasaki, K., and Kuroki, T. (1986). Activation of protein kinase $\mathrm{C}$ and specific phosphorylation of a $\boldsymbol{M}_{\mathrm{r}} 90,000$ membrane protein of promotable BALB/3T3 and C3H/10T $1 / 2$ cells by tumor promoters. Cancer Res. 46, 1055-1062.

ChOIE, D. D.. AND RICHTER, G. W. (1972). Cell proliferation in rat kidney induced by lead acetate and effects of uninephrectomy on the proliferation. Amer. I. Pathol. 66, 265-276.
Chole, D. D., AND Richter, G. W. (1974a). Cell proliferation in mouse kidney induced by lead. I. Synthesis of deoxyribonucleic acid. Lab. Invest. 30, 647-651.

Chole, D. D., AND RICHTER, G. W. (1974b). Cell proliferation in mouse kidney induced by lead. II. Synthesis of ribonucleic acid and protein. Lab. Invest. 30, 652656.

Clarkston, T. W., and KenCiI, J. E. (1958). Uptakc of lead by human erythrocytes in vitro. Biochem. J. 69 , 432-436.

Clasen, R. A.. Hartmann, J. F., Stark, A. J., Coo GAN, P. S., PANdOlFi, S., LAING, I.. BECKER, R., AND HASS, G. M. (1974). Electron microscopic and chemical studies of the vascular changes and edema of lead encephalopathy. Amer. J. Pathol. 74, 215-240.

CoHen, P. (1982). The role of protein phosphorylation in neural and hormonal control of cellular activity. Nature (London) 296, 613-620.

Columbano. A., Ledda, G. M.. Sirigu, P., Perra, T., AND PANI, P. (1983). Liver cell proliferation induced by a single dose of lead nitrate. Proc. R. Soc. Med. 60, 326-329.

Report from Committee on Environmental Hazards and Committee on Accident and Poison Prevention. (1987). Statement on childhood lead poisoning. Pediatrics $79,457-465$.

GIKAKD, P. R., MaZZEI, G. J., AND KUU, J. F. (1986). Immunological quantitation of phospholipid/ $\mathrm{Ca}^{2+}$. dependent protein kinase and its fragments. $J$. Biol. Chem. 261, 370-375.

GoldsteIN. G. W. (1984). Brain capillaries: A target for inorganic lead poisoning. Neurotoxicology 5, 167-176.

GoldsteIN, G. W., AND AR. D. (1983). Lead activates calmodulin sensitive processes. Life Sci. 33, 101-106.

Goldstein, G. W., Asbury, A. K., and Diamond, I. (1974). Pathogenesis of lead encephalopathy. Uptake of lead and reaction of brain capillaries. Arch. Neurol. 31, 382-389.

HABERMANN, E., AND RICHARDT, G. (1986). Intracellular calcium binding proteins as targets for heavy metal ions. Trends Pharmacol. Sci. 11, 298-300.

Homma, Y.. Henning-ChubB, C. B.. ANd Huberman, E. (1986). Translocation of protein kinase $C$ in human leukemia cells susceptible or resistant to differentiation induced by phorbol 12-myristate 13-acetate. Proc: Nall. Acad. Sir. USA 83, 7316-7319

Hunter, T., Ling, N., And CoOper, J. A. (1984). Protein kinase $C$ phosphorylation of the EGF receptor at a threonine residue close to the cytoplasmic face of the plasma membrane. Nature (London) 311, 480-483.

KIKKAWA, U., AND NishizUKA, Y. (1986). The role of protein kinase $C$ in transmembrane signalling. Annu. Re'v. Cell Biol. 2, 149-178.

KIKKAWA, U., TAKAI, Y.. MINAKUCHI, R.. INOHARA. S. AND NISHIZUKA. Y. (1982). Calcium-activated, phospholipid-dependent protein kinase from rat brain. Subcellular distribution, purification, and properties. J. Biol. Chem. 257, 13.341-13,348. 
Kikkawa, U., Takai, Y., Tanaka, Y., MiYake, R.. AND NishizUKA, Y. (1983). Protein kinase $C$ as a possible receptor protein of tumor-promoting phorbol esters. J. Biol. Chem. 258, 11,442-11,445.

Lamperi, P., Garro, F., and Pentschew, A. (1969). Lead encephalopathy in suckling rats. In Symposium () $)$ Brain Edema (I. Klatzo, Ed.), pp. 207-217. Springer-Verlag, New York

MahafFey, K. R., ANNEST, J. L., Roberts, J.. AND MURPHY, R. S. (1982). National estimates of blood lead levels: United States, 1976-1980. N. Engl. . Med. 307, 573-579.

Majerus, P. W., Wilson, D. B., Connolly, T. M., Bross. T. E., AND Neufeld. E. J. (1985). Phosphoinositide turnover provides a link in stimulus-response coupling. Trends Biochem. Sit 10, 168-171.

NaTHANSON, J. A., AND BLOOM, F. E. (1975). Lead-induced inhibition of brain adenylate cyclase. Nature (Londorl) 255, 419-420.

Nessler, E. J.. And Greengard, P. (1984). Protein Phosphorylation in the Nernots System. Wiley. New York.

Nedel, J. E., KuHN, L. J., AND VANDENbark, G. R. (1983). Phorbol diester receptor copurifies with protein kinase C. Proc: Natl. Acad. Sit $L S .4$ 80, 36-40.

NishizUkA, Y. (1984). The role of protein kinase $C$ in cell surface signal transduction and tumour promotion. Nattre (London) 308, 693-698.

NiSHIZUKA, Y. (1986a). Studies and perspectives of protein kinase C. Science 233, 305-312.

NishizUka. Y. (1986b). Perspectives on the role of protein kinase $C$ in stimulus-response coupling. $J$. Natl. Cuncer Inst. 76, 363-370.

OJAKIAN. G. K. (1981). Tumor promoter-induced changes in the permeability of epithelial cell tight junctions. Cell 23,95-103.

PENTSCHEW, A., AND GARRO, F. (1960). Lead encephalo-myelopathy of the suckling rat and its implications on the porphyrinopathic nervous diseases. Acta Neturonuthol 6, 266-278.

Pol:Nus, J. G. (1984). Effect of lead intoxication on calcium homeostasis and calcium-mediated cell function: A review. Netrotoxicology 5, 295-332.

POLINDS. J. G.. AND MitTelstaedt, R. A. (1983). Mobilization of cellular calcium-45 and lead-210: Effect of physiological stimuli. Science 220, 308-310.

Polinds. J. G., MORRison, D.. Wright, R.. Casciano. D. A. A.ND SHADDOCK. J. G. (1982), Effect of lead on calcium-mediated cell function in the isolated rat hepatocyte. Toxicol. Appl. Pharmacol 63, 402-408.

Press, M. F. (1977). Lead encephalopathy in neonatal Long-Evans rats: Morphologic studies. J. Neuropathol. Exp. Neurol. 36, 169-193.

PRESS, M. F. (1985). Lead-induced permeability changes in immature vessels of the developing cerebellar microcirculation. Acta Neuropathol. 67, 86-95.

REESE. T. S., AND KARNOVSKY. M. J. (1967). Fine structural localization of a blood-brain barrier to exogenous peroxidase. I. Cell Biol. 34, 207-217.

ROY, S., Hirano, A., KoChEN, J. A., ANd Zimmerman, H. M. (1974). Ultrastructure of cerebral vessels in chick embryo in lead intoxication. Acta Neuropathol. 30, 287-294.

SANO, K., TAKaI, Y., YAMANISHI, J., AND NishiZUKA. Y. ( 1983$)$. A role of calcium activated, phospholipiddependent protein kinase in human platelet activation. Comparison of thrombin and collagen actions. $J$. Biol. Chem. 258, 2010-2013.

Simons, T. J. B. (1986). Cellular interactions between lead and calcium. Brit. Med. Bull. 42, 431-434.

TAKAl, Y., KISHIMOTO, A., IWASA, Y., KAWAHARA, U., MORI, T., AND NishizUka, Y. (1979). Calcium-dependent activation of a multifunctional protein kinase by membrane phospholipids. J. Biol Chem. 254 . 3692-3695.

TAYLOR, D.. NATHANSON. J.. HOFFER, B.. OLSON, L.. AND SEIGER, A. (1978). Lead blockade of norepinephrine-induced inhibition of cerebellar purkinje neurons. J. Phamacol. Exp. Ther. 206, 371-381.

Thomas. J. A.. Dallenbach, F. D., and Thomas, M. (1973). Consideration on the development of experimental lead encephalopathy. J. Pathol. 109, 45-50.

Toews. A. D., Kolber, A., Hayward, J., Krigman. M. R.. AND MORELL, P. (1978). Experimental lead encephalopathy in the suckling rat: Concentration of lead in cellular fractions enniched in brain capillaries. Brain Res. 147, 131-138.

WITIERS, L. A., VATER, C. A.. AND LIERHARD, G. E. (1985). Phosphorylation of the glucose transporter in vitro and in vivo by protein kinase C. Nature (London) 315, 777-778.

Yoshimasa, T., Sibley, D. R., Bouvier. M., LefkoWITZ, R. J., AND CARON, M. G. (1987). Cross-talk between cellular signalling pathways suggested by phorbol-ester-induced adenylate cyclase phosphorylation. Nanture (Lomdon) 327,67-70. 